\title{
INVESTIGATION OF SEVERAL FACTORS ON ENZYMATIC HYDROLYSIS OF SUGAR BEET PULP AND CORN COB: STATISTICAL ANALYSES OF THE EXPERIMENTAL RESULTS
}

\author{
Berna Leyluhan Yurtseven ${ }^{1}$, Sevil Çıkrıkcı Erünsal ${ }^{2}$, Mecit Halil Öztop ${ }^{1,3 *}$ \\ ${ }^{1}$ Department of Biotechnology, Middle East Technical University, Ankara, Turkey \\ ${ }^{2}$ Department of Food Engineering, Konya Food and Agriculture University, Konya, Turkey \\ ${ }^{3}$ Department of Food Engineering, Middle East Technical University, Ankara, Turkey \\ Received / Geliş: 05.06.2021; Accepted / Kabul: 30.09.2021; Published online / Online bask1: 02.11.2021 \\ Leyluban-Yurtseven, B., Clknker-Erünsal, S., Öztop, M.H. (2021). Investigation of several factors on enzymatic \\ bydrolysis of sugar beet pulp and corn cob: Statistical analyses of the experimental results. GIDA (2021) 46 (6) 1369 - \\ 1385 doi: $10.15237 /$ gida.GD21104. \\ Leyluban-Yurtseven, B., Clkenkci-Erünsal, S., Ö:top, M.H. (2021). Şeker pancar küspesi ve mısır kocanmmn \\ enzimatik bidrolizinde farkl faktörlerin etkisinin incelenmesi: Deney sonuclarmm istatistiksel analizleri. GIDA (2021) \\ 46 (6) 1369-1385 doi: 10.15237/gida.GD21104.
}

\begin{abstract}
In this work, sugar beet pulp (SBP) as a lignin poor biomass and corn cob (CC) as a lignin rich biomass were subjected to enzymatic hydrolysis to see the effects of various variables on reducing sugar yield. In SBP hydrolysis, response surface methodology (RSM) and ANOVA were used to fit sugar yield and to determine significance of the parameters (substrate, pectinase, cellulase and hydrolysis time). The proposed quadratic model gave an adequate approximation indicating the significance of all main effects and some of the interaction effects $(\mathrm{p}<0.05)$. The maximum yields within the design space were found approximately as 87 $\mathrm{g} / \mathrm{L}$ after $18 \mathrm{~h}$ of hydrolysis, using $300 \mu \mathrm{l}$ Cellic Ctec3 and $300 \mu \mathrm{l}$ Pectinex Ultra SP-L at \%20 substrate loading. In CC hydrolysis, the use of nonionic surfactants (Tween 20 and Tween 80) under unpretreated conditions did not necessarily increase the yield of reducing sugar from untreated CC.

Keywords: Enzymatic hydrolysis, sugar beet, corn cob, statistical modeling, sugar yield

\section{ŞEKER PANCARI KÜSPESİ VE MISIR KOÇANININ ENZİMATİK HIIDROLİZINNDE FARKLI FAKTÖRLERİN ETKKİSİNIN İNCELENMESİ: DENEY SONUÇLARININ İSTATISTTIKSEL ANALİZLERİ}

\section{ÖZ}

Bu çalışmada, lignince düşük bir biyokütle olarak şeker pancarı küs pesinin (SBP) ve lignince yüksek bir biyokütle olarak mısır koçanının (CC) enzimatik hidrolizinden elde edilecek indirgen şeker veriminde, çeşitli değişkenlerin göstereceği etkiler araştırılmıştır. SBP hidrolizinde, çeşitli parametrelerin (substrat, pektinaz, selülaz ve hidroliz süresi) şeker verimi modeline önemini belirlemek için tepki yüzeyi metodolojisi (RSM) ve ANOVA kullanılmıştır. Önerilen ikinci dereceden model, tüm ana etkilerin ve bazı etkileşim etkilerinin önemini gösteren yeterli bir yaklaşıklık vermiştir $(P<0.05)$. Tasarım alanı içindeki maksimum verimler, $\% 20$ substrat yüklemesinde $300 \mu$ l Cellic Ctec3

${ }^{*}$ Corresponding author / Yazışmalardan sorumlu yazar
$\begin{array}{ll}\text { 11): mecit@metu.edu.tr } & \text { (D): }(+90) 3122105634\end{array}$

圆: (+90) 3122102767

Berna Leyluhan Yurtseven; ORCID no: 0000-0003-1842-3151

Sevil Çıkrıkcı Erünsal; ORCID no: 0000-0002-0459-4657

Mecit Halil Öztop; ORCID no: 0000-0001-6414-8942 
ve $300 \mu \mathrm{l}$ Pectinex Ultra SP-L enzimleri kullanılarak 18 saatlik hidrolizden sonra yaklaşık $87 \mathrm{~g} / \mathrm{L}$ olarak bulunmuştur. Ön işleme tabi tutulmamış CC hidrolizinde ise, iyonik olmayan surfektanların (Tween 20 ve Tween 80) indirgeyici şeker verimine fark yaratacak şekilde bir artırma etkisi görülmemiştir.

Anahtar kelimeler: Enzimatik hidroliz, şeker pancarı, mısır koçanı, istatiksel model, şeker verimi

\section{GİRİ̧}

Over the last decades, there has been an increasing demand to biofuels produced from lignocellulosic biomass because they act as ecofriendly, renewable and sustainable alternatives to fossil fuels (Sharma et al., 2019). Conversion of lignocellulosic biomass into such kind of valuable products such as bioethanol plays a significant role in reducing cost of energy as well as in decreasing the bad effects of fossil fuels on natural environment. Although it differs according to types of biomass, lignocellulosic biomass is mainly composed of cellulose, hemicellulose and lignin (Adaganti et al., 2014). The production of ethanol from lignocellulosic biomass involves several steps: pretreatment, acid or enzymatic hydrolysis, fermentation of monomeric sugars obtained from the enzymatic treatment of cellulosic and hemi cellulosic polymeric chains and finally the separation step (Adaganti et al., 2014). Especially, lignin covers the cellulose / hemicellulose and prevents enzymes to access them for the biochemical conversion. Thus, pretreatment methods could be required as the first step to break down the lignin structure and disrupt the crystalline structure of cellulose for enhancing enzymes accessibility to the cellulose (Zhang, 2008; Manisha and Yadav, 2017).

Sugar beet pulp (SBP) is one of the lignocellulosic biomasses that is an appropriate substrate for enzymatic hydrolysis to obtain reducing sugar which can be used for fermentation purposes afterwards. It is obtained as a by-product during beet processing in sugar factories (CieciuraWłoch et al., 2020). Its major constituents are composed of 30 wt. $\%$ hemicelluloses, 22-24 wt. $\%$ cellulose, and 15-25 wt. $\%$ pectin, around 5.9 wt. \% lignin with small amounts of fat, protein and ash (Berlowska et al., 2018). Since SBP could be classified as a lignin poor biomass, any pretreatment to SBP is not be needed prior to enzymatic hydrolysis. The studies are carried on keeping maximum polysaccharide fraction within the lignocellulosic biomass to obtain higher amount of total sugars (Van Dyk and Pletschke, 2012). Type and amount of hydrolytic enzymes (cellulases, hemicellulases, pectinases, ligninases, etc.), biological pretreatments methods, type of lignocellulosic feedstock, amount of substrate could be given among the factors affecting reducing sugar yields from such biomass (Paulova et al., 2015; Sharma et al., 2019). There are various studies related to use of commercial cellulases, pectinases and their combinations in different concentrations for beet fermentation (Nahar and Pryor, 2012, 2013; Ziemiński and KowalskaWentel, 2015; Berlowska et al., 2018) and other pretreatment strategies for high efficiency with low cost (Arenas-Cárdenas et al., 2017; Li et al., 2018; Arumugam et al., 2020). But still, our knowledge is limited regarding the complete use of hydrolases and hereby, appropriate enzyme combinations to maximize the saccharification has not been achieved, yet. At this point, Response surface methodology (RSM) could be proposed as a statistical approach for design of experiments, model building, evaluation of factor effects, optimization of responses and for the reduction of the required number of experiments (Yücel and Göycincık, 2015; Astray et al., 2016).

Corn cob (CC) is another lignocellulosic biomass and it could be considered as a lignin rich biomass due to its high lignin content. Average composition of dried corn cob consists of 36.3 $41.3 \%$ cellulose, $39.2-49.6 \%$ hemicellulose, 9.6 - $14.2 \%$ lignin and others (Pointner et al., 2014), hence pretreatment plays an important role on the reducing sugar yield from CC. It was shown in the past researches that surfactants caused to decrease the adsorption of enzymes to cellulose, to increase the available surface area of cellulose or to remove the lignin part during the hydrolysis. While non-ionic surfactants (Tween 80 and Tween 20) caused an increase in reducing sugar concentration during the hydrolysis of steam- 
exploded wood, the effect of anionic surfactants on hydrolysis rate was not as high as non-ionic ones, and cationic surfactant had no effect on the hydrolysis rate (Helle et al., 1993). According to the findings of Qing et al. (Qing et al., 2010), when Tween 80 was added before the pretreatment of corn stover, it was observed that pretreatment efficiency increased; lignin removal became higher, as the time was prolonged. However, there is a lack of studies to investigate the surfactant effect on hydrolysis rate of biomass without pretreatment.

The first objective of this study was to examine the effects of different factors (substrate loading, pectinase and cellulase loading, hydrolysis time) on the optimization of SBP hydrolysis for high sugar yield. Secondly, it was aimed to analyze enzymatic hydrolysis of CC by using different nonionic surfactants (Tween 20 and Tween 80) without need for any pretreatment method and to see their effects on the sugar yields. For these purposes, response surface methodology (RSM) as statistical analysis was evaluated in the first part of the study to optimize parameters of SBP hydrolysis. In the second part of the work, " $t$ " test was conducted to verify the statistical significance of the mean differences between the control group and samples in which surfactants were used.

\section{MATERIALS AND METHODS Materials}

SBP having a composition of $20-24 \%$ cellulose, 26-36 \% hemicellulose, $20-25 \%$ pectin and 1-2\% lignin was obtained from Kayseri Sugar Plant in Kayseri, Turkey. Prior to experiments, fresh SBP was dried at $105^{\circ} \mathrm{C}$ and milled (Kitchen type food processor) to $10 \mu \mathrm{m}-2 \mathrm{~mm}$ particle size to reduce crystallinity of lignocellulosic biomass. CC having a composition of $44.4 \%$ hemicellulose, $38.8 \%$ cellulose and $11.9 \%$ lignin were obtained from local markets in Ankara, Turkey, dried at $100{ }^{\circ} \mathrm{C}$ and ground to particle sizes between $10 \mu \mathrm{m}$ and 2 $\mathrm{mm}$ using a laboratory type mill (Laboratory Mill, Philadelphia, USA). Surfactants Tween 20 and Tween 80 were purchased from Merck (Germany).
Tri-sodium citrate dihydrate and citric acid monohydrate were purchased from Merck (Darmstadt, Germany). 3-5 Dinitrosalicylic acid, sodium sulfate and phenol were obtained from Sigma-Aldrich (St. Lois, MO, USA). Enzymes Pectinex Ultra SP-L (pectinase obtained from Aspergillus aculeatus) and Cellic Ctec3 (cellulase and hemicellulase complex) for SBP hydrolysis and Celluclast 1.5L and Novozyme 188 for CC hydrolysis were kindly provided by Novozymes (Bagsvaerd, Denmark). Pextinex activity is defined as 3,800 units/ $\mathrm{ml}$ in its specification sheet (Sigma Aldrich, USA). Activity of Novozyme 188, Celluclast $1.5 \mathrm{~L}$ were found as $450 \mathrm{CBU} / \mathrm{ml}$ and $82 \mathrm{FPU} / \mathrm{ml}$, respectively using the method stated by (Ghose, 1987). They were stored at $4^{\circ} \mathrm{C}$ when not in use. Activity of the enzymes were confirmed by AVICEL hydrolysis before each hydrolysis set.

\section{Enzymatic Hydrolysis Enzymatic Hydrolysis of SBP}

No pretreatment was applied prior to enzymatic hydrolysis due to the low lignin content of SBP. Before enzymatic hydrolysis, reducing sugar content of the SBP was found to be around 1.2 $\mathrm{g} / \mathrm{L}$. In design of the experiment, four parameters; substrate loading, two different enzyme loadings and time were determined as independent variables. Regarding to preliminary trials and optimum working conditions, the feasible substrate content for an appropriate experimental setup was chosen as 4, 8, 12, 16 and $20 \%$ solid/liquid ratio on dry basis. Considering previous studies and production cost, the selected enzymes, Pectinex Ultra SP-L and Cellic Ctec3 were combined at varying volumes of 100, 200, 300, 400 and $500 \mu \mathrm{l}$. Moreover, considering feasible hydrolysis rate and process conditions, hydrolysis time was particularly chosen as 6,12 , 18, 24 and $30 \mathrm{~h}$.

Enzymatic hydrolysis was conducted in a shaking incubator (Daihan Instruments, Germany) at 50 ${ }^{\circ} \mathrm{C}, 150 \mathrm{rpm}$ for 6 to $30 \mathrm{~h}$ using $0.05 \mathrm{M}$ sodium citrate buffer solution at $\mathrm{pH}$ 4.8. Samples were immersed into boiling water for 5 minutes to terminate the hydrolysis. Following this, samples were centrifuged at $13,000 \mathrm{rpm}$ for 3 minutes. Following the centrifugation, DNS method 
(Miller, 1959) was used to determine the reducing sugar content of the supernatant of the samples. Enzymatic hydrolysis was conducted in triplicates.

\section{Enzymatic Hydrolysis of CC}

Due to its high lignin content, CC needs pretreatment to obtain high yields of reducing sugar. In this study, costly pretreatment methods were not applied, instead, Tween 20 and Tween 80 were used to see the effect of surfactants when pretreatment step was eliminated. In order to see the effects of surfactants on the structure of cellulose, Avicel - pure cellulose - was used and selected as a control sample. Preliminary experiments were conducted both by simultaneous addition of surfactant and enzyme to the mixture and by sequential addition of surfactant and enzyme. Sequential addition comprised stirring of the solution for 24 hours at $450 \mathrm{rpm}$ before incubation. Working conditions of the shaking incubator were set at $50^{\circ} \mathrm{C}, 150$ rpm and hydrolysis lasted for 24 hours. Similar to the previous part, $0.05 \mathrm{M}$ sodium citrate buffer solution with a $\mathrm{pH}$ of 4.8 was used. Celluclast $1.5 \mathrm{~L}$ (cellulase enzyme) and Novozyme 188 (mainly composed of cellobiase) were the enzymes used. The volume of each enzyme was kept constant as $150 \mu \mathrm{l}$, since this was the optimum volume found in the study of Pocan et al. (2018) for the same substrate and the enzymes. Four different samples were prepared as follows: a mixture of $40 \%$ CC \& $60 \%$ Avicel, a mixture of $20 \%$ CC \& $80 \%$ Avicel, only Avicel sample and only CC sample. Enzyme volumes of $75 \mu \mathrm{l}$ and $300 \mu \mathrm{l}$ for each enzyme were tested. Experiments were conducted with the surfactant volumes of $135 \mu \mathrm{l}$, $250 \mu \mathrm{l}, 400 \mu \mathrm{l}, 500 \mu \mathrm{l}, 600 \mu \mathrm{l}, 1000 \mu \mathrm{l}, 3000 \mu \mathrm{l}$ and $5000 \mu \mathrm{l}$. After $24 \mathrm{~h}$ of hydrolysis time, samples were immersed in boiling water for 5 minutes to terminate the hydrolysis process. Finally, samples were centrifuged at $13,000 \mathrm{rpm}$ for 3 minutes. And then reducing sugar content of the supernatant samples were determined by DNS method. The experiments were conducted in triplicates.

\section{Determination of Reducing Sugar Content}

The DNS method was applied to determine reducing sugar content of the samples as given in the study of Miller (Miller, 1959). D - glucose was used as a standard for the DNS analysis. Before the addition of the DNS reagent, supernatant part of the medium from the enzymatic hydrolysis was diluted with distilled water. Ratio of the DNS agent was set as 1:1.5 on a volume basis. After the addition of the DNS reagent, obtained solution was maintained in a $100^{\circ} \mathrm{C}$ water bath for 5 minutes; then the color change in the solution was observed. A Hitachi U-1800 Optizen Pop Nano Bio spectrophotometer was used to measure absorbance of the samples at $540 \mathrm{~nm}$. Calibration curves were prepared to calculate the concentrations of reducing sugar in the samples.

\section{Experimental Design and Analysis}

Response Surface Methodology (RSM) Analysis for Enzymatic Hydrolysis of SBP

Screening design was firstly carried out to determine which of the several experimental variables and their interactions presented more significant effects. Since it is economical and effective, full fractional two-level factorial design was preferred for screening analysis at first. Then, fold - over mirror image of the original design was also used for screening analysis. Independent variables were selected as $\%$ substrate $(\mathrm{w} / \mathrm{v})\left(\mathrm{X}_{1}\right)$, amount of Pectinex Ultra SP-L $(\mu \mathrm{l})\left(\mathrm{X}_{2}\right)$, amount of Cellic Ctec3 ( $\mu \mathrm{l})\left(\mathrm{X}_{3}\right)$ and hydrolysis time (hours) $\left(\mathrm{X}_{4}\right)$. Response $(\mathrm{Y})$ was determined as the difference between the initial and final amount $(\mathrm{g} / \mathrm{L})$ of reducing sugar in SBP. The results of fractional factorial design pointed out that the main effects were significant on sugar yield response. Hereby, as a further study, a response surface model (RSM) was built up with a secondorder (quadratic) model, with a 5-point central composite design (CCD). This enabled to study the effects the aforementioned factors.

By using RSM, the experimental responses were analyzed with the following second-order polynomial, Eq. (1):

$$
\begin{aligned}
& Y=\beta_{0}+\sum_{i=1}^{k} \beta_{i} X_{i}+\sum_{i<j}^{k} \beta_{i j} X_{i} X_{j}+ \\
& \sum_{i=1}^{k} \beta_{i i} X_{i}^{2}
\end{aligned}
$$

where $\mathrm{Y}$ was the response (reducing sugars yield, $\left.\mathrm{g} \mathrm{L} \mathrm{L}^{-1}\right), \mathrm{Xi}$ and $\mathrm{Xj}$ were the coded independent variables. $\beta_{0}, \beta_{\mathrm{i}}, \beta_{\mathrm{ii}}$ and $\beta_{\mathrm{ij}}$ represented intercept, 
linear, quadratic and interaction constant coefficients, respectively. The contour plots were constructed using the fitted quadratic polynomial equations obtained from regression analysis.

The four factors were analyzed at 5 levels as given in Table 1a. CCD having 30 experimental runs with different combination of factors was developed using Minitab (ver.16.2.0.0, Minitab Inc., United Kingdom) in order to study the main effects and interactions. In order to provide uniform variance at any given radius from the center of the design mainly, rotatability and orthogonality, the axial distance, $\alpha$, was chosen to be 2 . The number of cube points, axial points, and center points in the design are 16, 8 and 6, respectively. To make each run in the design independent of each other, randomization tool of the software was used. The assigned run order was considered during the experiments. Finally, a half-factorial $2^{4}$ design using 5 point central composite design (CCD) leading to 3 sets of experiments was used to determine the most significant factors influencing reducing sugar yield of SBP.

Table 1a The coded and actual values of the levels of the independent factors

\begin{tabular}{|c|c|c|c|c|c|c|}
\hline \multirow[t]{2}{*}{$\begin{array}{l}\text { Independent } \\
\text { variables }\end{array}$} & \multirow[t]{2}{*}{ Symbols } & \multicolumn{5}{|l|}{$\begin{array}{l}\text { Coded } \\
\text { levels }\end{array}$} \\
\hline & & -2 & -1 & 0 & 1 & 2 \\
\hline & & $\begin{array}{l}\text { Actual } \\
\text { levels }\end{array}$ & & & & \\
\hline Substrate loading (w/v \%) & $\mathrm{X}_{1}$ & 4 & 8 & 12 & 16 & 20 \\
\hline Pectinex Ultra SP-L (Ml) & $\mathrm{X}_{2}$ & 100 & 200 & 300 & 400 & 500 \\
\hline Cellic Ctec3 ( $(\mu \mathrm{l})$ & $\mathrm{X}_{3}$ & 100 & 200 & 300 & 400 & 500 \\
\hline Hydrolysis time (h) & $\mathrm{X}_{4}$ & 6 & 12 & 18 & 24 & 30 \\
\hline \multicolumn{7}{|l|}{$\begin{array}{l}\text { Dependent } \\
\text { variables }\end{array}$} \\
\hline Sugar yield $(\mathrm{g} / \mathrm{L})$ & $\mathrm{Y}$ & & & & & \\
\hline
\end{tabular}

For the SBP data, classification and regression tree (CART) method, which is one of the important techniques of data mining was also used. A regression tree model was formed to investigate the effects of substrate content, enzyme amount and hydrolysis time on the reducing sugar amount of sugar beet pulp. 'rpart', a recursive partitioning tool developed by Therneau and Atkinson (2000) for R! statistical package, was used for the classification tree analysis. Moreover, reduced sugar amount was divided into quartiles and a classification tree model was estimated to predict the quartile class based on independent variables described above.

\section{Statistical Analysis}

Statistical analysis was evaluated in the first part of the study to optimize parameters of SBP hydrolysis. Analysis of variance (ANOVA) was conducted by using Minitab (ver.16.2.0.0, Minitab Inc., United Kingdom) in order to evaluate statistical significance of the models obtained by RSM and parameters in them. The results reported were the averages of three replicates. In RSM model, the second-order regression coefficients and equations were determined from the analysis of response surface design by using Minitab. According to the results of ANOVA and lack of fit test, only the factors affecting responses significantly were selected. No lack of fit was detected in the model for SBP hydrolysis. For statistical analysis of Avicel and CC hydrolysis, student ' $t$ ' test was conducted to verify the statistical significance of the mean differences between the control group and samples in which surfactants were used. 


\section{RESULTS AND DISCUSSION}

Determination of independent factors affecting the enzymatic hydrolysis of SBP

The effect of process variables such as temperature, $\mathrm{pH}$, enzyme type, reaction time, etc. on the product yield for biofuel production is a major issue to investigate. Substrate loading and reaction time are among the important factors that have the potential to maximize the reducing sugars but need to be optimized. Donkoh et al. (2012) obtained that pretreated SBP - with dilute sulfuric acid - loadings ranging from $0.66 \%$ and $2.34 \%$ did not have any significant effect on hydrolysis yield. However, SBP solid loadings, ranging from $2 \%$ to $10 \%$, led to the increase in the concentration of reducing sugars as expected. In another study, hydrolysis yield decreased from $45 \%$ (at a solid loading of $2 \%$ ) to $41.5 \%$ (at a solid loading of $10 \%$ ) after 72 hours of incubation (Zheng et al., 2012). The work conducted by Nahar et al. (2014) also revealed that SBP solid loadings from $10 \%$ to $16 \%$ increased the hydrolysate sugar concentrations, on the other hand, yields decreased at solid loadings above $10 \%$. To obtain high fermentable sugars, it is obvious that high solid loadings are necessary, whereas high solid content may adversely affect the process; mainly end-product inhibition in addition to mixing (Zheng et al., 2012). In that regard, five different substrate amounts (from 4 $\mathrm{g} / \mathrm{L}$ to $20 \mathrm{~g} / \mathrm{L}$ ) were determined to see the optimum range in this study. In the conversion of biomass to biofuels, the process time is another key factor influencing yield and chemical structure of the product (Siddiqui et al., 2019). Experimental researches show that it changes according to time of pretreated and untreated biomass. Adaganti et al. (2014) found an increase in glucose yield for untreated biomass up to $50 \mathrm{~h}$ of hydrolysis time but then a stabilization was observed at $70 \mathrm{~h}$ of hydrolysis. On the other hand, the yield showed an increasing trend for pretreated samples even after $50 \mathrm{~h}$. Pryor and Nahar (2015), Pocan et al. (2018) stated that $24 \mathrm{~h}$ of hydrolysis time was more representative time for hydrolysis rate and the need for high reactor productivity would discourage longer reaction times. In the light of all findings, hydrolysis time to be used in optimization was selected from $6 \mathrm{~h}$ to $30 \mathrm{~h}$ in SBP hydrolysis.

It was found that both cellulases and pectinases were important enzymes for the hydrolysis of sugar beet pulp. Although $\beta$-glucosidase can be used additionally, it was shown that hemicellulase was not needed to improve the effectiveness of hydrolysis (Zheng et al., 2012). The required enzyme dosage and synergistic effect between enzymes are valuable parameters in terms of process efficiency and economy. Arabinose, galacturonic acid, and galactose are the sugars obtained after the hemicellulose and pectin hydrolysis. In addition, glucose is produced at the end of cellulose hydrolysis. Kinnarinen and Häkkinen (2014) reported that doubling enzyme dosage did not led to duplication of glucose concentration. Multiple interactions occur between enzymes on complex substrates and this still requires investigation (Van Dyk and Pletschke, 2012). As a result, pectinase and cellulase as individual and mutual usage were studied in this design at five levels (from $100 \mu$ to $500 \mu \mathrm{l})$.

Fitting of The Models and The Results of Experimental Plans in Enzymatic Hydrolysis of SBP

CCD model was mainly performed to optimize the enzymatic hydrolysis factors. As given in Eq. (1), the second order polynomial equations were used to fit the responses after realizing that a firstorder approximation was not capable to express the relation (explained in the method section). A full quadratic model, i.e. a model consisting of first and second order polynomials of the predictors in addition to their interaction terms, was estimated.

To include unobserved variance into the model, five blocks were used in which each block represented a different day of the experiment.

To check whether models were adequate to fit, necessary assumptions were checked at each step. The residuals were assumed to be normally distributed with a constant variance and so normal probability curves of standardized 
residuals were drawn. An iterative approach was adopted to confirm normality. Observations with absolute standardized residual greater than 2 were removed from the data set and the full quadratic model was estimated again. This process was continued until the residuals were normally distributed with constant variance. Final experimental setup and responses were assigned based on CCD for the Response Surface Methodology (RSM) analysis (Supp. A.1).

Table 1b Response surface model estimation results

\begin{tabular}{|c|c|c|c|c|}
\hline Variable & $\begin{array}{c}\text { Coefficient } \\
\beta i \text { or } \beta i j\end{array}$ & Standard Error & $\mathrm{t}$ & $\mathrm{p}$ \\
\hline Constant, $\beta_{0}$ & 66.329 & 0.619 & 107.027 & 0.000 \\
\hline $\mathrm{X}_{1}$ & 16.026 & 0.341 & 47.047 & 0.000 \\
\hline $\mathrm{X}_{2}$ & 1.843 & 0.347 & 5.309 & 0.000 \\
\hline $\mathrm{X}_{3}$ & 1.369 & 0.354 & 3.866 & 0.001 \\
\hline $\mathrm{X}_{4}$ & 4.945 & 0.357 & 13.837 & 0.000 \\
\hline $\mathrm{X}_{1} * \mathrm{X}_{1}$ & -1.658 & 0.383 & -4.335 & 0.000 \\
\hline $\mathrm{X}_{3} * \mathrm{X}_{3}$ & -1.047 & 0.383 & -2.737 & 0.013 \\
\hline $\mathrm{X}_{1} * \mathrm{X}_{2}$ & 0.869 & 0.384 & 2.265 & 0.035 \\
\hline $\mathrm{X}_{1} * \mathrm{X}_{3}$ & 2.317 & 0.406 & 5.709 & 0.000 \\
\hline $\mathrm{X}_{1} * \mathrm{X}_{4}$ & 1.475 & 0.432 & 3.416 & 0.003 \\
\hline $\mathrm{X}_{2} * \mathrm{X}_{3}$ & 2.201 & 0.396 & 5.309 & 0.000 \\
\hline $\mathrm{X}_{2} * \mathrm{X}_{4}$ & 1.063 & 0.443 & 2.400 & 0.026 \\
\hline $\mathrm{X}_{3} * \mathrm{X}_{4}$ & -1.512 & 0.443 & -.3411 & 0.003 \\
\hline $\mathrm{R}^{2}$ & $99.41 \%$ & & & \\
\hline Adjusted $\mathrm{R}^{2}\left(\mathrm{R}_{\text {adj }}\right)$ & $98.95 \%$ & & & \\
\hline
\end{tabular}

Following this step, statistical significance of the regression coefficients was scrutinized. Similar to the previous phase, predictors with the lowest absolute $t$ statistics were discarded from the model one by one. The results based on analysis of variance (ANOVA) for the reduced quadratic model were displayed in Table $1 \mathrm{~b}$ with adjusted coefficient of determination ( $\mathrm{R}^{2}$ adj). All factors presented in the model were significant $(p<0.05)$ among which interaction of factors marked as $\mathrm{X}_{1}$ $* \mathrm{X}_{2}$ had the highest $\mathrm{p}$ value and thus the lowest impact on the response variable (yield).

$Y=\beta_{0}+\beta_{1} X_{1}+\beta_{2} X_{2}+\beta_{3} X_{3}+\beta_{4} X_{4}+$ $\beta_{11} X_{1}^{2}+\beta_{33} X_{3}^{2}+\beta_{12} X_{1} X_{2}+\beta_{13} X_{1} X_{3}+$ $\beta_{14} X_{1} X_{4}+\beta_{23} X_{2} X_{3}+\beta_{24} X_{2} X_{4}+\beta_{34} X_{3} X_{4}$
$Y=66.329+16.026 X_{1}+1.843 X_{2}+$

$1.369 X_{3}+4.945 X_{4}-1.658 X_{1}^{2}-$

$1.047 X_{3}^{2}+0.869 X_{1} X_{2}+2.317 X_{1} X_{3}+$

$1.475 X_{1} X_{4}+2.201 X_{2} X_{3}+1.063 X_{2} X_{4}-$

$1.512 X_{3} X_{4}$

It can be seen from the model equation (3) that sugar yield changed with substrate loading, enzyme loading and hydrolysis time, significantly $(p<0.05)$. As expected, increasing enzyme concentration with more concentrated substrate over a longer period increased the yield. On the other hand, second order effect coefficients for substrate amount $\left(\mathrm{X}_{1}{ }^{2}\right)$ and for Ctec $3\left(\mathrm{X}_{3}{ }^{2}\right)$ content were negative, suggesting optimal operation points might have existed for these variables. Moreover, the interaction term between 
Ctec 3 and time also had a negative coefficient. Therefore, it was hypothesized that the optimal values of the substrate amount, Ctec 3 concentration and hydrolysis time could be found to optimize the process yield. The interaction term for Ctec3 and Pectinex Ultra SP-L had a positive coefficient, indicating that these enzymes

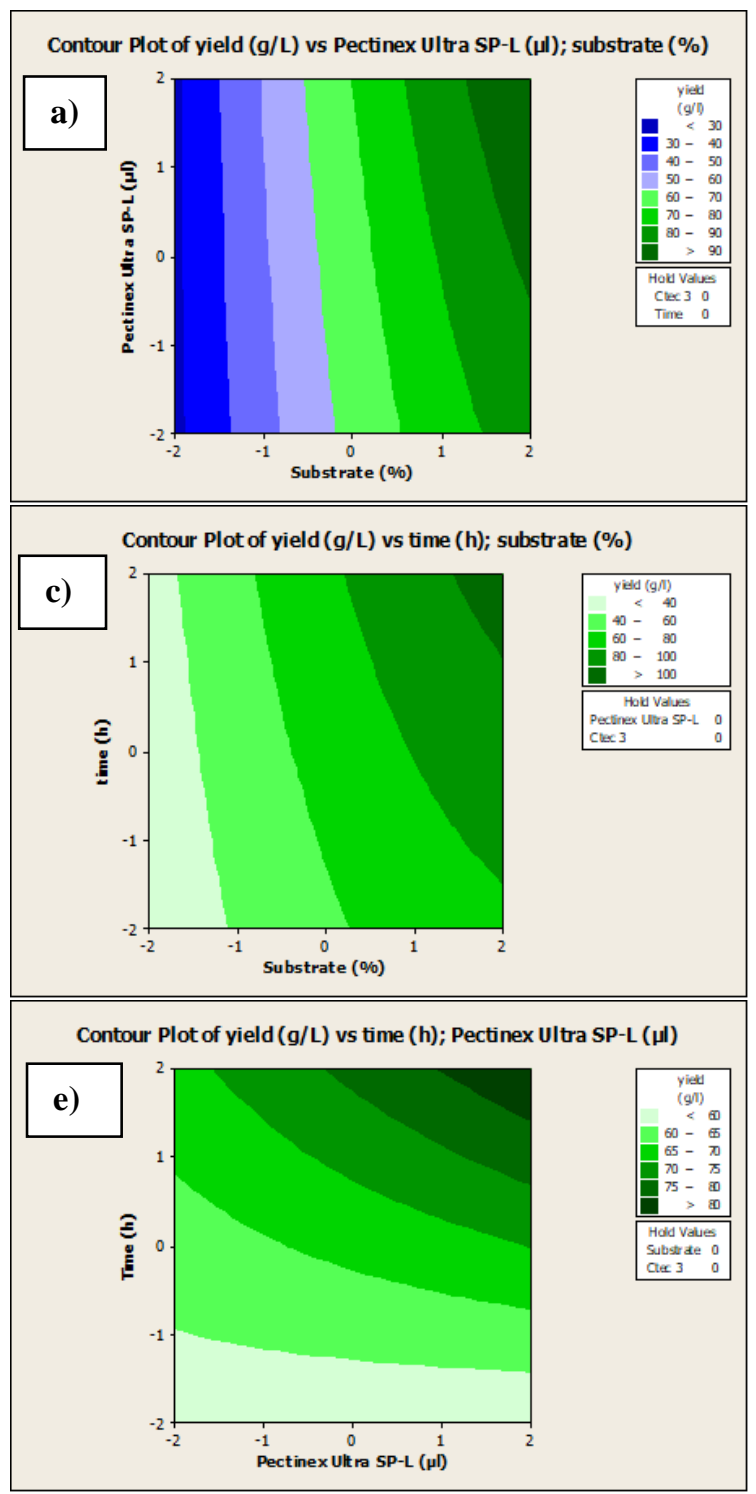

displayed a synergetic response. Analysis of variance for the final model was given in Supp. A.2. Findings of Nahar and Pryor (Nahar and Pryor, 2013) were consistent with our results by giving positive interaction between cellulase and pectinase addition in statistical model for ethanol production from sugar beets.

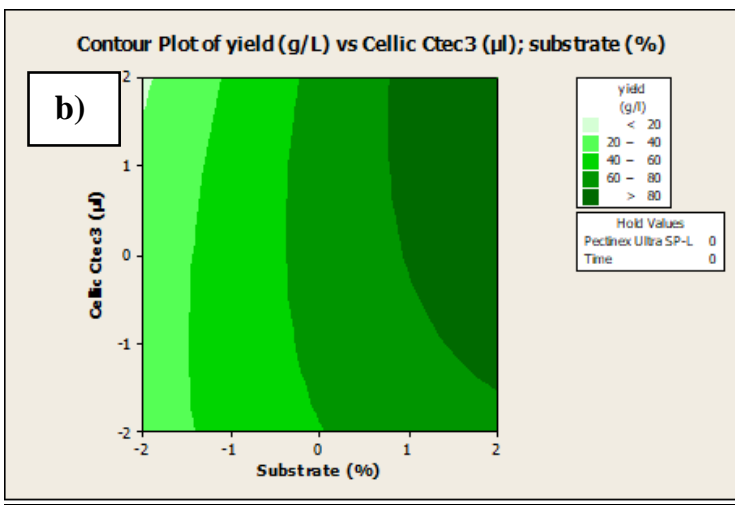

Contour Plot of yield (g/L) vs Cellic Ctec3 ( $\mu \mathrm{l})$; Pectinex Ultra SP-L ( $\mu \mathrm{l})$
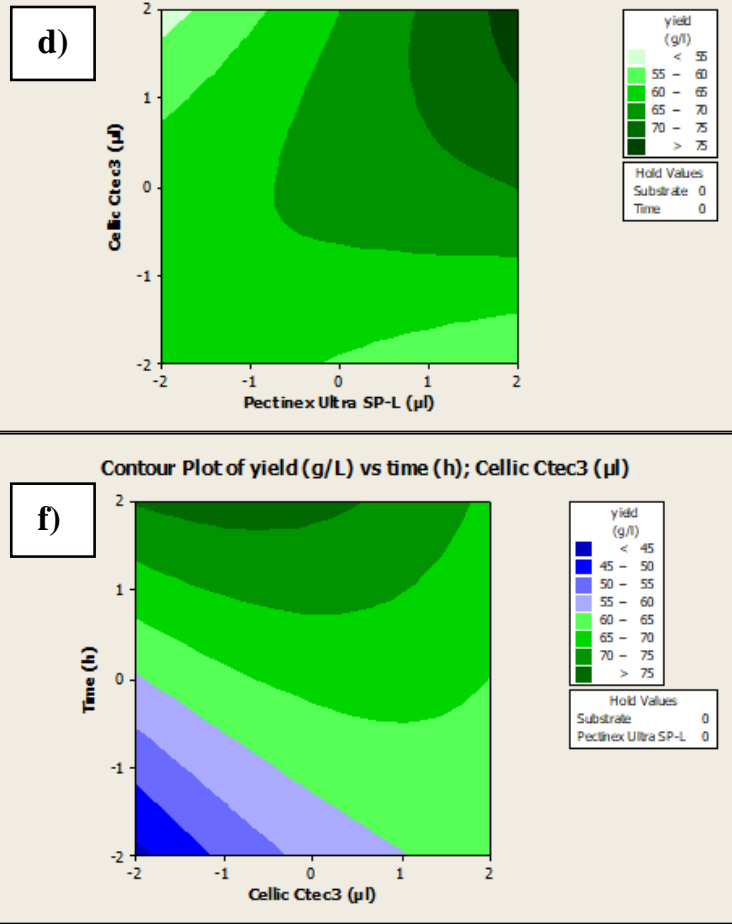

Fig. 1 Contour plot of a) yield vs Pectinex Ultra SP-L; substrate b) yield vs Cellic Ctec3; substrate c) yield vs time, substrate d) yield vs Cellic Ctec3, Pectinex Ultra SP-L e) yield vs time, Pectinex Ultra SPL f) yield vs time, Cellic Ctec 3 .

In order to better understand the relationship between the sugar yield and the independent variables, contour plots of predictor variable couples were formed in Figs. 1a-f. In overall, yield increased with higher amounts of substrate and enzyme concentration. Negative second order 
regression coefficient (antagonistic effect) for substrate amount suggested that yield should decline after a certain point, i.e. an optimal substrate amount should exist. However, estimation results also indicated that such an optimal substrate amount was well beyond the experimental range used in this study. Moreover, feasibility of the optimality of a higher substrate amount was equivocal. Difficulties were encountered during the trials while taking $1 \mathrm{ml}$ of supernatant from the samples containing 20\% substrate in order to conduct DNS assay. Therefore, it was almost impossible to find any supernatant in the sample above this percentage of substrate.

The plot corresponding to reducing sugars yield versus solids load and Pectinex Ultra SP-L concentration were shown in Fig. 1a. Pectinex Ultra SP-L was used to degrade pectin which is a complex organic polymer found in lignocellulosic biomass. It was seen from Fig. 1a that as the percent of substrate and enzyme volume increased, yield increased. When $20 \%$ substrate was used, as the volume of Pectinex Ultra SP-L was increased above $250 \mu$ l, the yield reached its maximum - above $90 \mathrm{~g} / \mathrm{L}$. It was inferred that the variation in substrate was relatively important than the variation in amount of Pectinex Ultra SP$\mathrm{L}$, since former affected the yield more. In addition, yield was almost constant at constant substrates as increasing enzyme volumes. As another finding given in Fig. 1b, the yield reached its maximum as the percent of substrate increased, even while using lower volumes of Cellic Ctec 3 -around $150 \mu \mathrm{l}$. When Fig. $1 \mathrm{~b}$ was compared with Fig. 1a, it could be referred that the lower substrate loading and Cellic Ctec3 volume led to slightly higher yields in Fig. 1b than the other. This result was expected since cellulose content was higher in SBP with respect to pectin.

Fig. 1c illustrated the contour plot of the interactive effects between substrate load and reaction time for the yield response. The amount of reducing sugar $(\mathrm{g} / \mathrm{L})$ increased with both higher substrate amount and longer reaction time as expected. During the hydrolysis of sugar beet pulp, it was shown in the previous studies that
$50 \%$ of hydrolysate was composed of galacturonic acid and arabinose after $48 \mathrm{~h}$ of incubation period. Sampling was done at the end of $12 \mathrm{~h}$ and $24 \mathrm{~h}$ incubation and it was observed that $50 \%$ and $80 \%$ of these monomers have been released at the end of $12 \mathrm{~h}$ and $24 \mathrm{~h}$, respectively (Leijdekkers et al., 2013). Another study indicated that $53 \%$ arabinose, $57 \%$ galactose and $44 \%$ rhamnose were released after $8 \mathrm{~h}$ of hydrolysis of SBP which were half of the monomers observed $48 \mathrm{~h}$ after hydrolysis (Micard et al., 1996).

Analysis results showed that combining Pectinex Ultra SP-L with Cellic Ctec3 created a synergetic response similar to previous studies (Pocan et al., 2018). In the same study (Pocan et al., 2018), total reducing sugar in orange peel hydrolysis did not vary significantly with increase of pectinase loading as cellulase kept constant at $56 \mathrm{FPU} / \mathrm{g}$. However, the increase of cellulase from 56 to 112 $\mathrm{FPU} / \mathrm{g}$ created significant change in glucose conversion. They also observed in pomegranate peels that if $67 \mathrm{IU} / \mathrm{g}$ pectinase was used with other enzyme loading of cellulase, the glucose concentration significantly changed in every significant change. These results also pointed out that the efficiency of enzyme combination could differ regarding to certain amount of enzyme and substrate type (with different cellulose and pectin content). In our study, as presented in Fig. 1d, $[1,1]$ combination (i.e. $400 \mu$ Pectinex Ultra SP-L and $400 \mu \mathrm{l}$ Ctec 3 ) gave a higher yield than $[2,0]$ or $[0,2]$ combinations. Similarly $[0,0]$ combination produced a higher yield than $[1,-1],[-1,1],[2,-2]$ and $[-2,2]$ combinations. As shown in Fig. 1e, obtained findings for the interaction of Pectinex Ultra SP-L and time were conformed with the expected outcome. Time had more effect on the extent of saccharification.

Negative interaction between reaction time and Cellic Ctec 3 content was finally presented in Fig. 1f. At longer hours, inhibition was observed at higher volumes of Cellic Ctec3. It could be expected because cellobiose or glucose formation could slow down the rate of hydrolysis by endproduct inhibition. At higher substrate loadings, end-product inhibition can similarly be observed, 
so it was also estimated that yield would drop beyond the experimental range.

\section{Classification and Regression Tree Analysis in Enzymatic Hydrolysis of SBP}

Regression tree, which was used to model the effects of substrate content, enzyme amount and hydrolysis time on the reducing sugar amount of SBP was shown in Fig. 2. Regression trees are used in graphically displaying the relationship between the dependent and independent variables. A heat-map format was evaluated to construct the regression tree, in which red represented the lower values of yield whereas higher values were designated with green. The resulting decision tree displayed the interaction of substrate amount and reaction time and the two different types of enzymes used in the experiments.

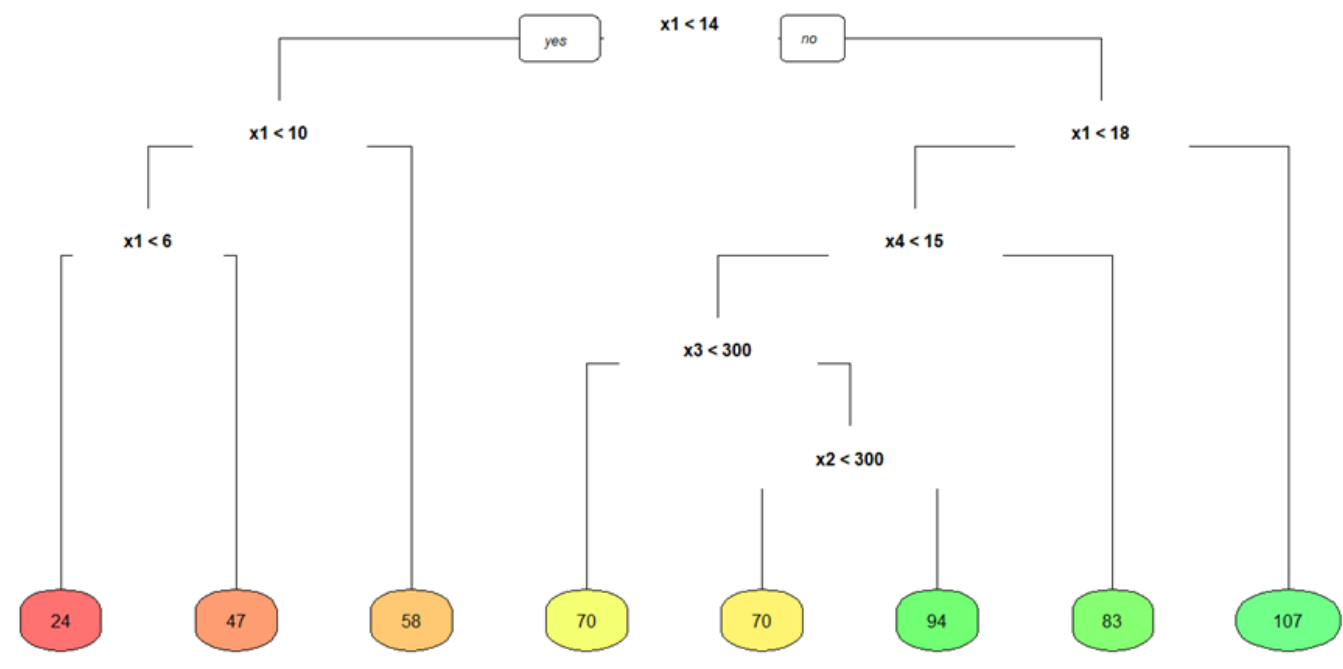

Fig. 2. Regression tree model for reducing sugar yield

Table 2a Rules derived from the regression tree

Rule

Reducing Sugar Yield

$\%$ substrate is smaller than $6 \%$

$24 \mathrm{~g} / \mathrm{L}$

$\%$ substrate is between $6 \%$ and $10 \%$

$47 \mathrm{~g} / \mathrm{L}$

$\%$ substrate is between $10 \%$ and $14 \%$

$58 \mathrm{~g} / \mathrm{L}$

$\%$ substrate is between $14 \%$ and $18 \%$ and reaction time is

$70 \mathrm{~g} / \mathrm{L}$

smaller than 15 hours and Cellic CTec 3 is larger than $300 \mu l$ and

Pectinex Ultra SP-L is smaller than $300 \mu \mathrm{l}$

$\%$ substrate is between $14 \%$ and $18 \%$ and reaction time is smaller than 15 hours and Cellic CTec 3 is smaller than $300 \mu \mathrm{l}$ $\%$ substrate is between $14 \%$ and $18 \%$ and reaction time is larger than 15 hours

$\%$ substrate is between $14 \%$ and $18 \%$ and reaction time is smaller than 15 hours and Cellic CTec3 is larger than $300 \mu l$ and

$70 \mathrm{~g} / \mathrm{L}$

$83 \mathrm{~g} / \mathrm{L}$

$94 \mathrm{~g} / \mathrm{L}$

Pectinex Ultra SP-L is larger than $300 \mathrm{Ml}$

$\%$ substrate is greater than $18 \%$
$107 \mathrm{~g} / \mathrm{L}$ 
Regression trees can be used to deduce rules from the resulting decision tree. In this sense, rules regarding the reduced sugar yield were summarized in Table 2a. On the other hand, classification tree, formed to predict the quartiles of reducing sugar yield, was also presented in Fig. 3. Substrate amount and reaction time dominated the classification results, hence obtained results confirmed the findings from other models.

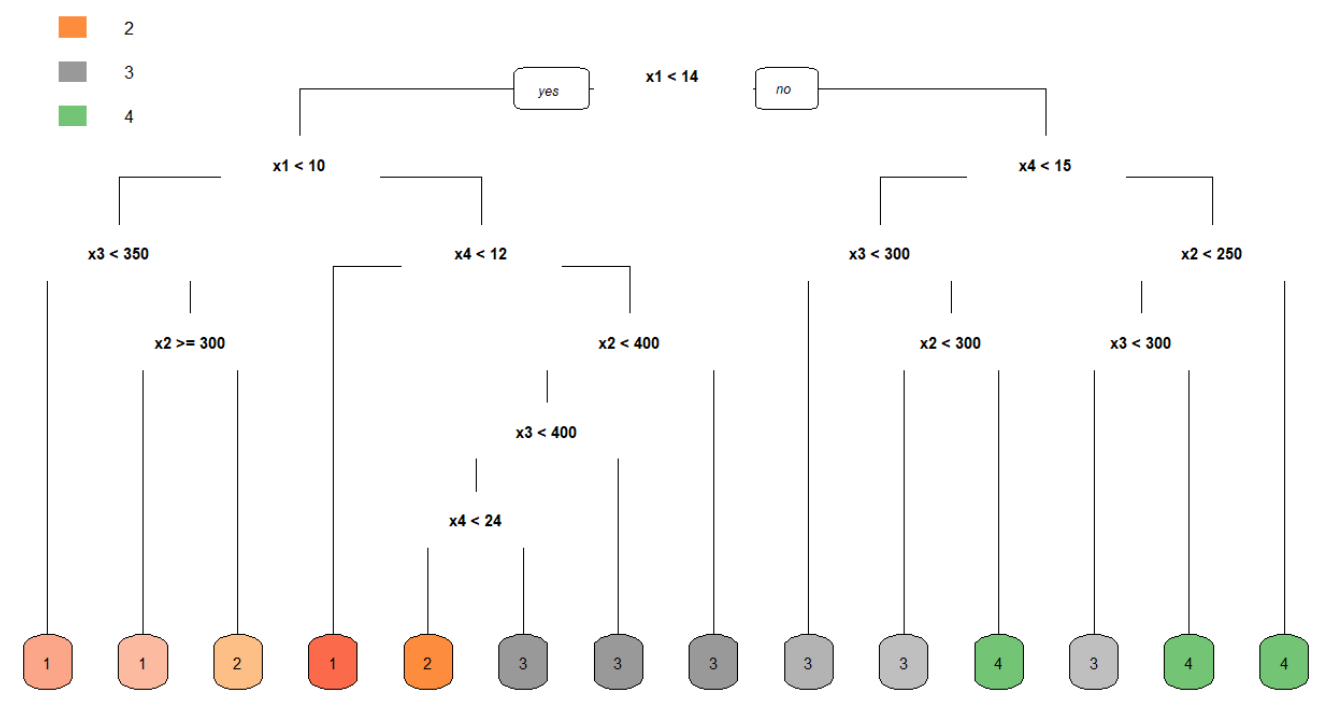

Fig. 3. Classification tree for reducing sugar yield quartiles

Quartile predictions from the classification tree were listed in Table $2 \mathrm{~b}$. The diagonal in Table $2 \mathrm{~b}$ showed the correct predictions by the classification tree. The classification tree model had an accuracy of $80 \%$, which indicated that 44 of the 55 cases were correctly classified. Based on all obtained results and models, it appeared that our reducing sugar yield was applicable and promising among the literature studies conducted to rapeseed straw (yield: $19 \mathrm{~g} / \mathrm{L}$ ) (Karagöz et al., 2012), palm spent tea waste (yield: $29 \mathrm{~g} / \mathrm{L}$ ) (Yücel and Göycıncık, 2015), reed (yield: $8 \mathrm{~g} / \mathrm{L}$ ) (Li et al., 2009) under varying pretreated conditions with varying enzymes.

Table 2b Classification tree predictions

\begin{tabular}{|c|c|c|c|c|c|}
\hline & & \multicolumn{4}{|c|}{ Predicted } \\
\hline \multirow{5}{*}{ Actual } & $<25^{\text {th }}$ Percentile & $\begin{array}{c}>25^{\text {th }} \text { Percentile } \\
<50^{\text {th }} \text { Percentile }\end{array}$ & $\begin{array}{c}>50^{\text {th }} \text { Percentile } \\
<75^{\text {th }} \text { Percentile }\end{array}$ & $>75^{\text {th }}$ Percentile \\
\cline { 2 - 6 } & \begin{tabular}{c}
$<25^{\text {th }}$ Percentile \\
\hline $25^{\text {th }}$ Percentile
\end{tabular} & 12 & 2 & 0 & 0 \\
\cline { 2 - 6 } & $\begin{array}{l}>50^{\text {th }} \text { Percentile } \\
<75^{\text {th }} \text { Percentile }\end{array}$ & 3 & 10 & 0 & 0 \\
\cline { 2 - 6 } & $>75^{\text {th }}$ Percentile & 0 & 1 & 11 & 0 \\
\hline
\end{tabular}




\section{Effects of Surfactants on Enzymatic Hydrolysis of CC}

Pretreatment is a necessary strategy to make cellulose more accessible to enzymatic conversion, to suppress lignocellulosic recalcitrance and to improve hydrolysis rates. Various physical (grinding, milling, etc.), chemical (acid hydrolysis, alkali pretreatment, inorganic salt addition, ammonia steeping, etc.), thermochemical (steam explosion, etc.) and biological pretreatments (the use of microorganisms) are commonly used in biomass conversion (Arumugam et al., 2020). There are several studies about the use of surfactants and increasing the yield of cellulose conversion but most of them did not eliminate the pretreatment steps. A pretreatment strategy for the steamexploded corncobs was conducted by Zheng et al. (2014) using a modified twin-screw extruder with the addition of Tween 80 during enzymatic hydrolysis. They found out that for the extruded corncobs with 7\% xylose removal, Tween 80 did not have a significant impact on the conversion of glucose. On the other hand, for corncobs with $80 \%$ xylose removal, an increase in the Tween 80 concentration led to the increase in the glucose conversion when the hydrolysis time was prolonged to $72 \mathrm{~h}$ (Zheng et al., 2014). Another old study of Kaar and Holtzapple (1998) observed an increase from 50 to $80 \mathrm{mg}$ equivalent glucose/g dry corn stover, on sugar yield when they used Tween 80 on pretreated samples. They also found that Tween 20 was more effective when compared with Tween 80, during the hydrolysis of pretreated corn stover. In addition, at high substrate concentrations, it was seen that the presence of surfactant was effective during the saccharification of pretreated corn stover (Kaar and Holtzapple, 1998). In another study although, the adsorption of cellulase decreased with the addition of Tween 20 in steam-pretreated spruce (SPS) hydrolysis medium, there was no significant decrease in enzyme adsorption when delignified SPS and Avicel used (Eriksson et al., 2002).

In this study, to see the effects of surfactant use under unpretreated conditions (just milling of the samples) on reducing sugar yield of Avicel (cellulose as control sample) and CC, two different types of nonionic surfactants, namely Tween 20 and Tween 80 were incorporated into the hydrolysis reaction. Enzyme amount, pulp content, and hydrolysis time were kept constant at $300 \mu \mathrm{L}$ (Cellulast 150 ML, Novozyme $150 \mu \mathrm{L}$ ), $3 \%(\mathrm{w} / \mathrm{v})$ solution and 24 hours, respectively. Obtained results are presented in Table 2c.

Table 2c Reducing sugar yield of Avicel treated with Tween 20 and Tween 80

\begin{tabular}{lcccccc}
\hline Group & Observations & $\begin{array}{c}\text { Minimum } \\
(\mathrm{g} / \mathrm{L})\end{array}$ & $\begin{array}{c}\text { Maximum } \\
(\mathrm{g} / \mathrm{L})\end{array}$ & Mean $(\mathrm{g} / \mathrm{L})$ & $\begin{array}{c}\text { Standard } \\
\text { Deviation }\end{array}$ & $\begin{array}{c}\text { Coefficient of } \\
\text { Variation }\end{array}$ \\
\hline Control & 22 & 11.36 & 26.68 & 21.19 & 4.36 & $20.57 \%$ \\
Tween 20 & 15 & 17.49 & 32.06 & 22.55 & 3.61 & $16.00 \%$ \\
Tween 80 & 15 & 16.43 & 28.56 & 23.32 & 3.00 & $12.86 \%$ \\
\hline
\end{tabular}

The mean yield of samples containing surfactants was found to be higher than that of the control group. $t$ test $(95 \%$ confidence level) was conducted to verify the statistical significance of the mean differences between the control group and samples in which surfactants were used (Supp B). Although the previous studies showed that the inclusion of surfactants Tween 20 and Tween 80 could increase the reducing sugar yield, t-test results in this study did not give significant mean difference between treated and control groups ( $p$
$<0.05)$. Even trials with lower and higher amounts of surfactants (T20, $135 \mu$ l through 500 $\mu \mathrm{l})$, higher and lower amounts of enzymes (300 $\mu \mathrm{l}$ $+300 \mu \mathrm{l}, 75 \mu+75 \mu \mathrm{l})$, various substrate compositions (40\% CC + 60\% Avicel, 20\% CC + $80 \%$ Avicel, $100 \%$ CC) did not give statistically different results $(\mathrm{p}<0.05)$. The reason could be related to the lack of any pretreatment application to the samples. Therefore, it was concluded that surfactant use without any other pretreatment while keeping the other parameters constant (i.e. 
enzyme content, substrate amount and hydrolysis time) did not necessarily increase the reducing sugar yield from CC.

Another reason could be related to the impact of surfactants on crystalline structure that is among the factors influencing yield efficiency. During the pretreatment process, the structure of lignin surfaces changes so enzymes are easily adsorbed by the lignin surfaces (Eriksson et al., 2002). When substrates with various lignin composition were hydrolyzed, it was observed that presence of lignin highly affected the adsorption capacity of Tween 20 giving higher value than pure cellulose. On the other hand, since there was no linear relationship between the lignin amount and the adsorption capacity, it was concluded that acidic groups within the substrate or $\mathrm{pH}$ of the medium might be effective on adsorption behavior of Tween 20. Structural changes in Avicel and the substrate with highest amounts of lignin were not observed. Although structural changes were observed within the other samples having various amount of lignin composition, it was inferred that Tween 20 effect on crystalline structure was not substantial (Seo et al., 2011). Thus, it could be another reason not to obtain a significant difference between control and treated samples.

\section{CONCLUSION}

The present study was carried out to see the effects of different factors on hydrolysis efficiency of lignin rich and lignin poor biomass, separately. SBP as a lignin poor biomass was studied to optimize several enzymatic hydrolysis parameters (substrate amount, enzyme type and amount, hydrolysis time). The results demonstrated that the equation of a secondorder-polynomial model fitted well with the experimental data of reducing sugar yield. The maximum yields within the design space were approximately $87 \mathrm{~g} / \mathrm{L}$ after $18 \mathrm{~h}$ of hydrolysis, using $300 \mu \mathrm{l}$ Cellic Ctec 3 and $300 \mu \mathrm{l}$ Pectinex Ultra SP-L at $\% 20$ substrate loading. In correspondence with the regression models, an increase in cellulase and pectinase loadings results resulted in an increase in sugar release. The results proposed the potential of RSM for determination of optimum hydrolysis conditions of SBP. A larger range of enzyme concentrations might be needed to be further investigated to observe optimum concentration.

$\mathrm{CC}$ as a lignin rich biomass was also analyzed to examine the effect of non-ionic surfactants (Tween 20 and Tween 80) on the reducing sugar yield. The results revealed that surfactants Tween 20 and Tween 80 did not necessarily increase the reducing sugar yield.

Considering the models implemented and the results obtained, it can be concluded that both lignin poor and rich wastes have the potential to obtain high sugar yields by manipulating process conditions.

\section{FUNDING}

The study got funding from Middle East Technical University, Research and Coordination Unit, with the grant \# BAP-07-02-2017-004-056

\section{CONFLICT OF INTEREST}

Authors declare no conflict of interest.

\section{AUTHORS' CONTRIBUTIONS}

The study was derived from MSc thesis of Mrs. Yurtseven. She conducted all experiments and analyses and was involved in writing. Dr. Cikrikci Erunsal drafted the manuscript and contributed to the statistical analyses of data. Dr. Oztop was the PI of the study and finalized the manuscript.

\section{REFERENCES}

Adaganti, S.Y., Yaliwal, V.S., Kulkarni, B.M., Desai, G.P., Banapurmath, N.R. (2014). Factors Affecting Bioethanol Production from Lignocellulosic Biomass (Calliandra calothyrsus). Waste Biomass Valorization, 5, 963-971.

Arenas-Cárdenas, P., López-López, A., MoellerChávez, G.E., León-Becerril, E. (2017). Current Pretreatments of Lignocellulosic Residues in the Production of Bioethanol. Waste Biomass Valorization, 8, 161-181.

Arumugam, A., Malolan, V.V., Ponnusami, V. (2020). Contemporary Pretreatment Strategies for Bioethanol Production from Corncobs: A Comprehensive Review. Waste Biomass Valorization, 12, 577-612. 
Astray, G., Gullón, B., Labidi, J., Gullón, P. (2016). Comparison between developed models using response surface methodology (RSM) and artificial neural networks (ANNs) with the purpose to optimize oligosaccharide mixtures production from sugar beet pulp. Ind Crops Prod, 92, 290-299.

Atkinson, E.J., Therneau, T.M. (2000). Plotting options. In: An Introduction to Recursive Partitioning Using the RPART Routines. Mayo Foundation

Berlowska, J., Binczarski, M., Dziugan, P., Wilkowska, A., Kregiel, D. , Witonska, I. (2018). Sugar Beet Pulp as a Source of Valuable Biotechnological Products. Adv Biotechnol for Food Ind. Elsevier Inc. 359-392.

Cieciura-Włoch, W., Borowski, S., Otlewska, A. (2020). Biohydrogen production from fruit and vegetable waste, sugar beet pulp and corn silage via dark fermentation. Renew Energy, 153, 12261237.

Donkoh, E., Degenstein, J., Tucker, M., Ji, Y. (2012). Optimization of Enzymatic Hydrolysis of Dilute Acid Pretreated Sugar Beet Pulp Using Response Surface Design. J Sugarbeet Res, 49, 2637.

Dyk, J.S. Van., Pletschke, B.I. (2012). A review of lignocellulose bioconversion using enzymatic hydrolysis and synergistic cooperation between enzymes-Factors affecting enzymes, conversion and synergy. Biotechnol Adv, 30, 1458-1480.

Eriksson, T., Börjesson, J., Tjerneld, F. (2002). Mechanism of surfactant effect in enzymatic hydrolysis of lignocellulose. Ensyme Microb Technol, 31, 353-364.

Ghose, T.K. (1987). Measurement of cellulase activities. Pure Appl Chem, 59, 257-268.

Helle, S.S., Duff, S.J.B., Cooper, D.G. (1993). Effect of surfactants on cellulose hydrolysis. Biotechnol Bioeng, 42, 611-7.

Kaar, W.E., Holtzapple, M.T. (1998). Benefits from Tween during enzymic hydrolysis of corn stover. Biotechnol Bioeng, 59, 419-27.

Karagöz, P., Rocha, I. V., Özkan, M., Angelidaki, I. (2012). Alkaline peroxide pretreatment of rapeseed straw for enhancing bioethanol production by Same Vessel Saccharification and Co-Fermentation. Bioresour Technol, 104, 349-57.

Kinnarinen, T., Häkkinen, A. (2014). Influence of enzyme loading on enzymatic hydrolysis of cardboard waste and size distribution of the resulting fiber residue. Bioresour Technol, 159, 136142.

Leijdekkers, A.G.M., Bink, J.P.M., Geutjes, S., Schols, H.A., Gruppen, H. (2013). Enzymatic saccharification of sugar beet pulp for the production of galacturonic acid and arabinose; a study on the impact of the formation of recalcitrant oligosaccharides. Bioresour Technol, 128, 518-525.

Li, G., Sun, Y., Guo, W., Yuan, L. (2018). Comparison of various pretreatment strategies and their effect on chemistry and structure of sugar beet pulp. J Clean Prod, 181, 217-223.

Li, H., Kim, N.J., Jiang, M., Kang, J.W., Chang, H.N. (2009). Simultaneous saccharification and fermentation of lignocellulosic residues pretreated with phosphoric acid-acetone for bioethanol production. Bioresour Technol, 100, 3245-3251.

Manisha., Yadav, S.K. (2017). Technological advances and applications of hydrolytic enzymes for valorization of lignocellulosic biomass. Bioresour Technol, 245, 1727-1739.

Micard, V., Renard, C.M.G.C., Thibault, J.F. (1996). Enzymatic saccharification of sugar-beet pulp. Ensyme Microb Technol, 19, 162-170.

Miller, G.L. (1959). Use of Dinitrosalicylic Acid Reagent for Determination of Reducing Sugar. Anal Chem, 31, 426-428.

Nahar, N., Pryor, S.W. (2012). Enzymatic hydrolysis and fermentation of whole sugar beets for ethanol production. In: Am Soc Agric Biol Eng Annu Int Meet 2012, AS ABE 2012.

Nahar, N., Pryor, S.W. (2013). Enzymatic hydrolysis and fermentation of crushed whole sugar beets. Biomass Bioenergy, 59, 512-519. 
Nahar, N., Rorick, R., Pryor, S.W. (2014). Effects of enzyme and solids loading on sugar beet pulp hydrolysis. Biol Eng Trans, 7, 17-26.

Paulova, L., Patakova, P., Branska, B., Rychtera, M., Melzoch, K. (2015). Lignocellulosic ethanol: Technology design and its impact on process efficiency. Biotechnol Adv, 33, 1091-107.

Pocan, P., Bahcegul, E., Oztop, M.H., Hamamci, H. (2018). Enzymatic Hydrolysis of Fruit Peels and Other Lignocellulosic Biomass as a Source of Sugar. Waste Biomass V alorization, 9, 929-937.

Pointner, M., Kuttner, P., Obrlik, T., Jäger, A., Kahr, H. (2014). Composition of corncobs as a substrate for fermentation of biofuels. Agron Res, 12, 391-396.

Pryor, S.W., Nahar, N. (2015). $\beta$-glucosidase supplementation during biomass hydrolysis: How low can we go? Biomass Bioenergy, 80, 298-302.

Qing, Q., Yang, B., Wyman, C.E. (2010). Impact of surfactants on pretreatment of corn stover. Bioresour Technol, 101, 5941-51.

Seo, D.J., Fujita, H., Sakoda, A. (2011). Structural changes of lignocelluloses by a nonionic surfactant, Tween 20, and their effects on cellulase adsorption and saccharification. Bioresour Technol, 102, 9605-9612.

Sharma, H.K., Xu, C., Qin, W. (2019). Biological Pretreatment of Lignocellulosic Biomass for Biofuels and Bioproducts: An Overview. Waste Biomass V alorization, 10, 235-251.
Siddiqui, M.T.H., Nizamuddin, S., Mubarak, N.M., Shirin, K., Aijaz, M., Hussain, M., Baloch, H.A. (2019). Characterization and Process Optimization of Biochar Produced Using Novel Biomass, Waste Pomegranate Peel: A Response Surface Methodology Approach. Waste Biomass Valorization, 10, 521-532.

Yücel, Y., Göycıncık, S. (2015). Optimization and Modelling of Process Conditions Using Response Surface Methodology (RSM) for Enzymatic Saccharification of Spent Tea Waste (STW). Waste Biomass Valorization, 6, 1077-1084.

Zhang, Y.H.P. (2008). Reviving the carbohydrate economy via multi-product lignocellulose biorefineries. J Ind Microbiol Biotechnol, 35, 367375.

Zheng, J., Choo, K., Bradt, C., Lehoux, R., Rehmann, L. (2014). Enzymatic hydrolysis of steam exploded corncob residues after pretreatment in a twin-screw extruder. Biotechnol Rep, 3, 99-107.

Zheng, Y., Cheng, Y.S., Yu, C., Zhang, R., Jenkins, B.M., VanderGheynst, J.S. (2012). Improving the efficiency of enzyme utilization for sugar beet pulp hydrolysis. Bioprocess Biosyst Eng, 35, 1531-1539.

Ziemiński, K., Kowalska-Wentel, M. (2015). Effect of enzymatic pretreatment on anaerobic co-digestion of sugar beet pulp silage and vinasse. Bioresour Technol, 180, 274-280. 


\section{Supplementary Materials}

Supp. A.1 Final experimental setup for five-level, four-factor response surface design and the experimental data with coded and actual values of variables

\begin{tabular}{|c|c|c|c|c|c|c|}
\hline & $\begin{array}{c}\text { \% Substrate } \\
(\mathrm{w} / \mathrm{v})\end{array}$ & $\begin{array}{c}\text { Pectinex } \\
\text { Ultra SP-L } \\
(\mu \mathrm{l})\end{array}$ & $\begin{array}{l}\text { Cellic Ctec3 } \\
\text { (Ml) }\end{array}$ & Time (h) & & \\
\hline Observation & $\mathrm{X} 1$ & $\mathrm{X} 2$ & $\mathrm{X} 3$ & $\mathrm{X} 4$ & Block & Yield $(\mathrm{g} / \mathrm{L})$ \\
\hline 1 & -1 & 1 & 1 & -1 & 1 & 53.56 \\
\hline 2 & 1 & 1 & -1 & -1 & 1 & 70.78 \\
\hline 3 & 1 & -1 & 1 & -1 & 1 & 72.52 \\
\hline 4 & -1 & -1 & -1 & -1 & 1 & 50.08 \\
\hline 5 & 1 & 1 & 1 & 1 & 1 & 86.87 \\
\hline 6 & 1 & -1 & -1 & 1 & 1 & 89.64 \\
\hline 7 & -1 & -1 & 1 & 1 & 1 & 50.83 \\
\hline 8 & -1 & 1 & -1 & 1 & 1 & 58.42 \\
\hline 9 & -1 & 1 & -1 & -1 & 2 & 53.63 \\
\hline 10 & -1 & -1 & 1 & -1 & 2 & 56.59 \\
\hline 11 & 1 & -1 & -1 & -1 & 2 & 82.29 \\
\hline 12 & 1 & 1 & 1 & -1 & 2 & 94.41 \\
\hline 13 & -1 & 1 & 1 & 1 & 2 & 64.26 \\
\hline 14 & 1 & -1 & 1 & 1 & 2 & 95.41 \\
\hline 15 & -1 & -1 & -1 & 1 & 2 & 45.71 \\
\hline 16 & 1 & 1 & -1 & 1 & 2 & 99.77 \\
\hline 17 & 0 & 0 & 0 & 0 & 3 & 56.98 \\
\hline 18 & 1 & 1 & 1 & 0 & 3 & 85.70 \\
\hline 19 & -1 & 1 & -1 & 0 & 3 & 45.73 \\
\hline 20 & 0 & 0 & 2 & 0 & 3 & 61.45 \\
\hline 21 & 2 & 0 & 0 & 0 & 3 & 87.39 \\
\hline 22 & 0 & 2 & 0 & 0 & 3 & 66.98 \\
\hline 23 & 0 & 0 & -2 & 0 & 3 & 54.82 \\
\hline 24 & 0 & -2 & 0 & 0 & 3 & 56.82 \\
\hline 25 & -2 & 0 & 0 & 0 & 3 & 23.98 \\
\hline 26 & 0 & 0 & 0 & 0 & 3 & 61.68 \\
\hline 27 & 0 & 0 & 0 & 0 & 4 & 56.22 \\
\hline 28 & 1 & 1 & 1 & 0 & 4 & 84.91 \\
\hline 29 & 0 & 0 & 0 & 0 & 4 & 53.17 \\
\hline 30 & 0 & 0 & 0 & 0 & 4 & 56.73 \\
\hline 31 & 0 & 0 & 0 & 0 & 4 & 57.06 \\
\hline 32 & 0 & 0 & 0 & -2 & 4 & 46.91 \\
\hline 33 & 0 & 0 & 0 & 2 & 4 & 67.74 \\
\hline 34 & -1 & 1 & 1 & 1 & 4 & 35.93 \\
\hline 35 & 1 & -1 & 1 & 1 & 4 & 71.68 \\
\hline 36 & 1 & -1 & -1 & 1 & 4 & 71.24 \\
\hline 37 & -1 & 1 & 1 & -1 & 5 & 40.33 \\
\hline 38 & 1 & 1 & -1 & -1 & 5 & 65.34 \\
\hline 39 & -1 & -1 & 1 & 1 & 5 & 39.77 \\
\hline 40 & 1 & -1 & 1 & -1 & 5 & 70.30 \\
\hline 41 & -1 & -1 & -1 & -1 & 5 & 42.40 \\
\hline 42 & -1 & 1 & -1 & -1 & 5 & 44.13 \\
\hline 43 & -1 & -1 & -1 & 1 & 5 & 39.69 \\
\hline 44 & 1 & 1 & -1 & 1 & 5 & 78.80 \\
\hline 45 & -1 & -1 & 1 & -1 & 5 & 48.66 \\
\hline 46 & 1 & -1 & -1 & -1 & 5 & 64.51 \\
\hline
\end{tabular}


Supp. A.2. ANOVA Results for 'yield'

\begin{tabular}{lllllll}
\hline Source & DF & Seq SS & Adj SS & Adj MS & F & P \\
\hline Blocks & 4 & 1929.8 & 2089.56 & 522.39 & 168.72 & 0.000 \\
Regression & 12 & 8575.4 & 8575.41 & 714.62 & 230.81 & 0.000 \\
Linear & 4 & 8155.3 & 7980.17 & 1995.04 & 644.37 & 0.000 \\
X1 & 1 & 7540.5 & 6853.04 & 6853.04 & 2213.42 & 0.000 \\
X2 & 1 & 76.2 & 87.27 & 87.27 & 28.19 & 0.000 \\
X3 & 1 & 65.7 & 46.29 & 46.29 & 14.95 & 0.001 \\
X4 & 1 & 472.9 & 592.77 & 592.77 & 191.45 & 0.000 \\
Square & 2 & 65.7 & 63.80 & 31.90 & 10.30 & 0.001 \\
X1*X1 & 1 & 42.0 & 58.17 & 58.17 & 18.79 & 0.000 \\
X3*X3 & 1 & 23.7 & 23.19 & 23.19 & 7.49 & 0.013 \\
Interaction & 6 & 354.3 & 354.33 & 59.06 & 19.07 & 0.000 \\
X1*X2 & 1 & 0.7 & 15.89 & 15.89 & 5.13 & 0.035 \\
X1*X3 & 1 & 81.5 & 100.90 & 100.90 & 32.59 & 0.000 \\
X1*X4 & 1 & 89.9 & 36.13 & 36.13 & 11.67 & 0.003 \\
X2*X3 & 1 & 108.5 & 87.26 & 87.26 & 28.18 & 0.000 \\
X2*X4 & 1 & 37.8 & 17.83 & 17.83 & 5.76 & 0.026 \\
X3*X4 & 1 & 36.0 & 36.03 & 36.03 & 11.64 & 0.003 \\
Residual Error 20 & 61.9 & 61.92 & 3.10 & & \\
Lack-of-Fit & 17 & 52.4 & 52.36 & 3.08 & 0.97 & 0.598 \\
Pure Error & 3 & 9.6 & 9.56 & 3.19 & & \\
Total & 36 & 10567.1 & & & & \\
\hline
\end{tabular}

Supp. B.1. Group mean comparison between Tween 20 and Control

\begin{tabular}{lllll}
\hline Group & Mean Difference & $\begin{array}{l}95 \% \\
\text { Interval }\end{array}$ & Confidencet value & Degrees of Freedom \\
\hline Control vs Tween 201.35 & -1.42 & 4.12 & 0.99 \\
$\mathrm{H}_{0}:$ Difference $=0$ & $\mathrm{P}(|\mathrm{T}|>|\mathrm{t}|)=0.33$ & $\begin{array}{l}\text { Difference in means is not statistically } \\
\text { significantly different from zero } \\
\mathrm{H}_{2}: \text { Difference }>0\end{array}$ & $\mathrm{P}(\mathrm{T}>\mathrm{t})=0.16$ & $\begin{array}{l}\text { Difference in means is not statistically } \\
\text { significantly different from zero }\end{array}$ \\
\hline
\end{tabular}

Supp. B.2. Group mean comparison between Tween 80 and Control

\begin{tabular}{lllll}
\hline Group & Mean Difference & $\begin{array}{l}95 \% \\
\text { Interval }\end{array}$ & Confidencet value & Degrees of Freedom \\
\hline Control vs Tween 802.12 & -0.51 & 4.76 & 1.64 \\
$\mathrm{H}_{0}:$ Difference $=0$ & $\mathrm{P}(|\mathrm{T}|>|\mathrm{t}|)=0.11$ & $\begin{array}{l}\text { Difference in means is not statistically } \\
\text { significantly different from zero } \\
\text { Difference in means is not statistically } \\
\text { significantly different from zero }\end{array}$ \\
\hline
\end{tabular}

